\title{
MEDIA PEMBELAJARAN BERBASIS IT SEBAGAI INOVASI PEMBELAJARAN PADA JENJANG TAMAN KANAK-KANAK (STUDI KASUS GURU TAMAN KANAK-KANAK MUSLIMAT NU MASLAKUL HUDA)
}

\author{
M. Ghofar Rohman; Purnomo Hadi Susilo \\ m.ghofarrohman@unisla.ac.id; hadyjelak.purnomo@gmail.com \\ Program Studi Teknik Informatika, Fakultas Teknik Universitas Islam Lamongan
}

\begin{abstract}
ABSTRAK
The purpose of this research was to determine the improvement of the ability of kindergarten teachers in the preparation of learning media, and to improve the ability of teachers to innovate in developing information technology(IT)-based learning media. The problem in education in kindergarten lies in the ability of teachers in teaching and learning activities in which teachers teach without developing their abilities in developing learning media used, the lack of teachers' ability to use computers, and lack of willingness to improve creativity in providing learning media.This research uses a classroom action research (CAR) model with a collaborative model between the cycle models developed by Kemmis and Taggar. The results of this study indicate that there is an increase starting from the initial research activities there is a percentage of the ability of teachers in developing learning media is equal to $49.62 \%$, the percentage of teacher completeness is $23.08 \%$. Finally, in the second cycle there was an increase in the percentage of the teacher's ability to develop learning media at $91.54 \%$, the percentage of teacher's completeness was $100 \%$. the improvement of teacher information technology competencies can stimulate teachers to innovate in developing learning media.
\end{abstract}

Kata kunci: Learning Media, Kindergarten Teachers, Information Technology.

\section{PENDAHULUAN}

Guru sebagai pendidik harus mempunyai kompetensi dalam mengelola pembelajaran (UU No. 14 Tahun 2005 tentang Guru dan Dosen). Salah satunya yaitu mampu menyajikan pembelajaran dengan menggunakan media yang menyenangkan dan berkesan bagi anak. permasalahan yang ada dalam pendidikan di TK terletak pada minimnya kemampuan guru dalam menggunakan komputer, serta kurangnya kemampuan guru mengembangkan kemampuanya dalam menyusun media pembelajaran yang digunakan dalam mengajar, sehingga anak akan cepat bosan ketika kegiatan pembelajaran di kelas.

Pendidikan anak usia dini yang dilakukan di Taman Kanak-Kanak merupakan upaya stimulasi pada anak agar seluruh potensinya berkembang secara optimal sesuai tahap usianya. Peran guru sebagai pendidik dan pengasuh serta pembimbing dalam pelaksanaan pendidikan anak usia dini harus mampu memberikan kemudahan kepada anak untuk mempelajari terhadap pembelajaran yang disampaikan oleh guru. Pembelajaran yang dilakukan berpusat pada anak dengan menggunakan pendekatan pembelajaran saintifik yang mencakup rangkaian proses mengamati, menanya, mengumpulkan informasi, menalar, dan mengomunikasikan. Keseluruhan proses tersebut dilakukan dengan menggunakan seluruh indera serta berbagai sumber dan media pembelajaran.

Menurut (Wardaya \& Sumartini, 2016) merancang media pembelajaran di TK sangat penting dilakukan oleh seorang guru dalam setiap kegiatan, apapun jenis kegiatannya faktor perencanaaan ini sangat 
penting untuk diperhatikan. Senada dengan itu menurut (Karwati \& Priansa, 2014) media pembelajaran merupakan perantara untuk menyalurkan atau menyampaikan pesan kepada pihak lain dalam hal ini adalah menyampaikan materi pelajaran kepada siswa. Sementara (Nurseto, 2011) menyatakan bahwa media pembelajaran adalah wahana penyalur pesan dan informasi dalam kegiatan pembelajaran. Media pembelajaran yang dirancang secara baik akan sangat membantu peserta didik mencapai tujuan pembelajaran yang dicita-citakan. Penggunaan media pembelajaran dapat memperlancar proses pembelajaran dan mengoptimalkan hasil belajar siswa.

Salah satu media pembelajaran yang dapat digunakan dalam pembelajaran adalah media pembelajaran berbasis IT, Penggunaan IT sebagai media pembelajaran dapat berbentuk file slide Power Point, gambar, animasi, video, audio, program CAI (Computer Assisted Instruction), program simulasi, dan lainlain. Media pembelajaran berbasis IT sangat bagus untuk diterapkan saat pembelajaran karena peserta didik lebih tertarik pada media yang berbasis teknologi sehingga peserta didik akan lebih antusias saat kegiatan pembelajaran. Media yang digunakan dalam kegiatan pembelajaran di taman kanak-kanak harus dipilih dengan seksama yang seharusnya dapat menggambarkan nilai-nilai yang membentuk jati diri siswa (Majid, 2012)

Microsoft power point adalah suatu softwere yang akan membantu dalam menyusun sebuah persentasi yang efektif, professional, dan juga mudah. Microsoft power point akan membantu sebuah gagasan lebih baik menarik dan jelas tujuannya jika di persentasikan karena Microsoft power point akan membantu dalam pembuatan slide, outline persentasi , menampilkan slide yang dinamis, termasuk clip art yang menarik, yang mudah dilayar monitor komputer(Arsyad, 2014).
Tujuan penelitian ini adalah meningkatkan kompetensi guru TK dalam mengembangkan kemampuan menciptakan media pembelajaran berbasis IT. Mengetahui pentingnya meningkatkan kemampuan guru TK untuk terus berinovasi dalam mendidik anak usia dini. Mengetahui efektivitas media pembelajaran berbasis IT untuk perkembangan kemampuan anak usia dini.

\section{METODE}

Penelitian ini menggunakan pendekatan kuantitatif, dengan metode penelitian tindakan kelas model kolaboratif dengan acuan model siklus peneliian tindakan kelas yang dikembangkan oleh Kemmis dan Taggart (Arikunto, 2010). Penelitian ini dilaksanakan di TK Maslakul Huda Dengok Paciran Lamongan, dengan subyek penelitian adalah 13 guru TK Maslakul Huda Dengok.

Penelitian dilakukan oleh penulis dengan berkolaborasi dengan pelatih atau pemateri dan observer, instrumen penelitian menggunakan observasi, dan teknik analisis data menggunakan kuantitatif deskriptif. Penelitian dilakukan dalam beberapa putaran (siklus) yang dimaksudkan untuk memperbaiki sistem pengarahan yang telah dilaksanakan. Setiap siklus ada 1 pertemuan dan 4 tahapan yang akan dilaksanakan yaitu, perencanaan, pelaksanaan, pengamatan, dan refleksi (Arikunto, 2010).

Pengumpulan data pada penelitian ini dilakukan dengancara observasi partisipatif yang dilakukan oleh observer dengan pemateri. Data yang didapat kemudian diolah dengan: (1) pengecekan kelangkapan data; (2) pentabulasian data; dan (3) analisis data. Analisis yang dipergunakan adalah teknik deskriptif dengan menggunakan persentase. 


\section{HASIL DAN PEMBAHASAN}

\section{Kondisi Pra Tindakan}

Kondisi awal ketuntasan guru taman kanak-kanak Muslimat Miftahul Huda Dengok Paciran Lamongan yang didapatkan dengan melakukan pre test pada materi pengembangan media pembelajaran, ditunjukkan pada tabel 1 sebagai berikut:

Tabel 1. Hasil Observasi Kondisi Awal

\begin{tabular}{|c|c|c|}
\hline No & Aspek Penilaian & $\begin{array}{c}\text { Presentase Pra } \\
\text { Tindakan }\end{array}$ \\
\hline \multirow[t]{2}{*}{1} & Kemampuan & $49,62 \%$ \\
\hline & $\begin{array}{l}\text { Pengembangan } \quad \text { Media } \\
\text { Pembelajaran }\end{array}$ & \\
\hline 2 & $\begin{array}{l}\text { Persentase Jumlah Guru } \\
\text { yang tuntas }\end{array}$ & $23,08 \%$ \\
\hline
\end{tabular}

Berdasarkan hasil analisis table 1, hasil pre-test pada pra tindakan menunjukkan bahwa presentase kemampuan guru dalam mengembangkan media pembelajaran adalah sebesar 49,62\%. Dan presentase ketuntasan guru sebesar 23,08\%, hal ini menunjukan adanya guru yang nilai ketuntasanya lebih kecil daripada yang tidak tuntas yaitu sebesar 76,92\%, dengan rincian dari 13 guru yang menjadi peserta, sebanyak 3 orang peserta yang nilainya tuntas, dan sisanya sebanyak 10 orang peserta tidak tuntas. Oleh Karena itu penelitian perlu untuk dilaksanakan siklus I.

\section{Pelaksanaan Tindakan Kelas Siklus I}

$$
\text { Pada pelaksanaan siklus I }
$$

penelitian tindakan kelas, dari materi tentang media pembelajaran dengan menggunakan power point. Hasil monitoring selama kegiatan pada siklus I adalah terdapat peningkatan kualitas proses dan hasil dalam kegiatan pembuatan media poembelajaran dengan menggunakan power point. Aktivitas peserta pelatihan secara pribadi lebih baik dalam mengikuti pelatihan dan menunjukkan semangat belajar yang lebih besar daripada sebelumnya, namun hasil kemajuan dari tiap peserta terdapat perbedaan atau bervariasi. Dari hasil observasi pelatihan media pembelajaran di siklus I dapat dilihat pada uraian tabel 2 dibawah ini:

Tabel 2. Hasil Observasi Siklus I

\begin{tabular}{|c|c|c|c|c|}
\hline $\begin{array}{l}\mathbf{N} \\
\mathbf{0}\end{array}$ & $\begin{array}{c}\text { Aspek } \\
\text { Penilaian }\end{array}$ & $\begin{array}{c}\text { Presenta } \\
\text { se Pra } \\
\text { Tindaka } \\
\text { n } \\
\end{array}$ & $\begin{array}{c}\text { Persenta } \\
\text { se Siklus } \\
\text { I }\end{array}$ & $\begin{array}{l}\text { Persentas } \\
\text { e } \\
\text { Peningkat } \\
\text { an }\end{array}$ \\
\hline 1 & $\begin{array}{l}\text { Persentase } \\
\text { Kemampuan } \\
\text { Pengemban } \\
\text { gan Media } \\
\text { Pembelajara } \\
\mathrm{n}\end{array}$ & $49,62 \%$ & $69,42 \%$ & $19,81 \%$ \\
\hline 2 & $\begin{array}{l}\text { Persentase } \\
\text { Jumlah } \\
\text { Guru yang } \\
\text { tuntas }\end{array}$ & $23,08 \%$ & $53,85 \%$ & $30,77 \%$ \\
\hline
\end{tabular}

PRESENTASE PRATINDAKAN KE SIKLUS 1

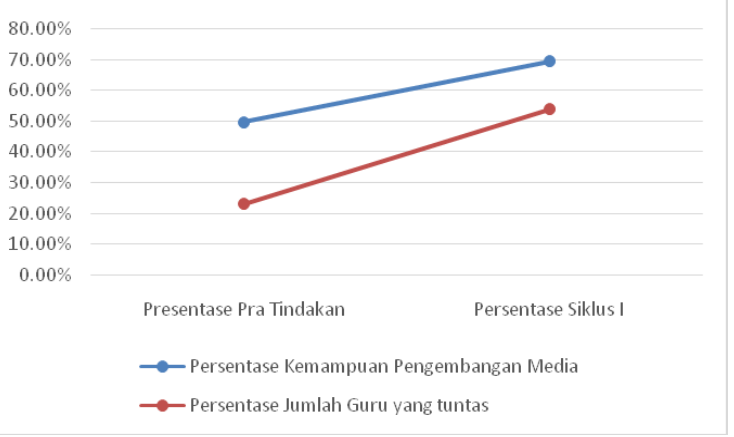

Berdasarkan hasil analisis table 2 di atas, Kesimpulan yang didapatkan dari hasil observasi siklus I menunjukkan bahwa mengalami nilai presentase kemampuan guru dalam mengembangkan media pembelajaran mengalami peningkatan dari $49,62 \%$ pada pra tindakan meningkat menjadi $69,42 \%$ pada siklus I dengan peningkatan mencapai $19,81 \%$. Guru yang mencapai ketuntasan sebesar 53,85\%, hal ini menunjukan adanya peningkatan presentase pada kegiatan siklus I, tetapi masih ada beberapa guru yang kemampuan dalam mengembangkan media pembelajaran belum berkembang secara maksimal. Oleh Karena itu penelitian perlu untuk dilanjutkan pada siklus II. 


\section{Pelaksanaan Tindakan Kelas Siklus II}

Hasil monitoring selama kegiatan pada siklus II adalah terdapat peningkatan kualitas proses dan hasil dalam kegiatan pembuatan media pembelajaran yang secara pribadi lebih baik daripada sebelumnya pada siklus I, namun hasil kemajuan dari peserta masih terdapat perbedaan atau bervariasi. Dari hasil observasi pelatihan media pembelajaran di siklus II dapat dilihat pada uraian tabel 3 dibawah ini:

Tabel 3. Hasil Observasi Siklus II

\begin{tabular}{clccc}
\hline $\begin{array}{c}\text { N } \\
\text { o }\end{array}$ & \multicolumn{1}{c}{$\begin{array}{c}\text { Aspek } \\
\text { Penilaian }\end{array}$} & $\begin{array}{c}\text { Persenta } \\
\text { se Siklus } \\
\text { I }\end{array}$ & $\begin{array}{c}\text { Persenta } \\
\text { se Siklus } \\
\text { II }\end{array}$ & $\begin{array}{c}\text { Persentas } \\
\text { e } \\
\text { Peningkat } \\
\text { an }\end{array}$ \\
\hline 1 & $\begin{array}{l}\text { Persentase } \\
\text { Kemampuan } \\
\text { Pengemban } \\
\text { gan Media }\end{array}$ & $69,42 \%$ & $91,54 \%$ & $22,12 \%$ \\
2 & & & \\
Persentase & $53,85 \%$ & $100 \%$ & $46,15 \%$ \\
& $\begin{array}{l}\text { Jumlah } \\
\text { Guru yang } \\
\text { tuntas }\end{array}$ & & & \\
\hline
\end{tabular}

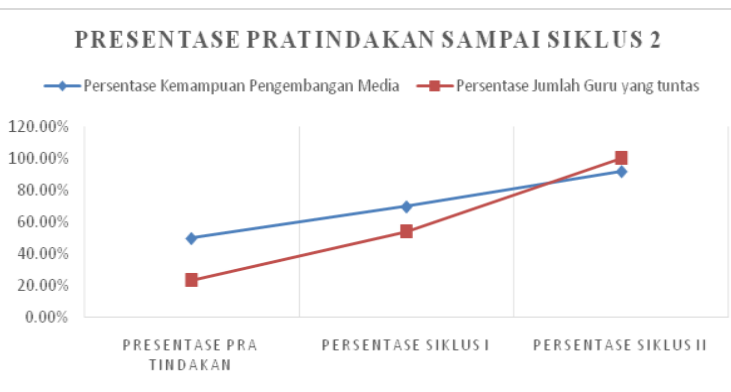

Berdasarkan hasil analisis table 3 di atas, Kesimpulan yang didapatkan dari hasil observasi siklus II menunjukkan nilai presentase kemampuan guru dalam mengembangkan media pembelajaran mengalami peningkatan dari $69,42 \%$ pada siklus I meningkat menjadi $91,54 \%$ pada siklus II dengan peningkatan mencapai $22,12 \%$. Guru yang mencapai ketuntasan sebesar $100 \%$, hal ini menunjukan adanya peningkatan presentase pada kegiatan siklus II, hal ini menunjukkan ketuntasan secara keseluruhan guru dalam mengembangkan media pembelajaran karena pencapaian persentase ketuntasan telah melebihi $75 \%$.

\section{KESIMPULAN}

Simpulan pada penelitian ini antara lain: (1) meningkatnya kemampuan guru dalam mengembangkan media pembelajaran berbasis IT, hal ini terlihat pada meningkatnya presentase kemampuan pengembangan media pembelajaran guru sebesar $41,62 \%$ dari kegiatan pra tindakan sebesar 49,62\% menjadi 91,54\% pada siklus II, (2) Dengan meningkatnya kompetensi TIK guru dapat menstimulasi guru untuk berinovasi dalam mengembangkan media pembelajaran, hal ini dapat dilihat dari adanya peningkatan sebesar $96,92 \%$ pada presentase jumlah guru. (3) Peningkatan kompetensi guru berproyeksi terhadap efektifitas media pembelajaran pada perkembangan anak usia dini.

\section{Saran}

Saran bagi guru untuk terus meningkatkan kemampuan dalam menggunakan komputer, meningkatkan kreativitas untuk berinovasi dalam peningkatan kompetensi-kompetensinya. Untuk penelitian selanjutnya disarankan untuk melakukan penelitian pada media pembelajaran yang telah dibuat oleh guru dan efektifitasnya saat diimplementasikan pada siswa. Sehingga dapat dilihat hasil dari media pembelajaran yang dibuat oleh guru pada pembelajaran dikelas, selanjutnya guru dapat memahami pentingnya posisi media pembelajaran dalam sebuah proses belajar mengajar sehingga proses pembelajaran menjadi lebih menarik bagi siswa.

\section{UCAPAN TERIMA KASIH}

Terima kasih yang sebesarbesarnya kami sampaikan pada pihak DRPM Ristekdikti atas dana yang telah diberikan dalam skim penelitian dosen pemula. 


\section{DAFTAR PUSTAKA}

Arikunto, S. (2010). Prosedur Penelitian. Jakarta: Rineka Cipta.

Arsyad, A. (2014). Media Pembelajaran. Jakarta: Raja Grafindo Persada.

Karwati, E., \& Priansa, D. J. (2014). Manajemen Kelas. Bandung: Alfabeta.

Majid, L. B. (2012). Penerapan Nilai Murni dan Pembentukan Jati Diri Kanak-Kanak Prasekolah Melalui Penggunaan Multimedia (Integrating Noble Values and Identity Formation into Kindergarten Children through the Use of Multimedia). Jurnal Hadhari Special Edition, 51-65. Retrieved from http://ejournal.ukm.my/jhadhari/art icle/download/12297/3906

Nurseto, T. (2011). MEMBUAT MEDIA PEMBELAJARAN YANG MENARIK. Jurnal Ekonomi \& Pendidikan, Vol. 8, 19-35. Retrieved from https://journal.uny.ac.id/index.php/ jep/article/download/706/570

Wardaya, C. U., \& Sumartini, T. (2016). Media dan sumber belajar di TK. Bandung: PPPPTK TK DAN PLB BANDUNG. Retrieved from https://tkitassalafushsholih.files.wo rdpress.com/2016/09/modul-tkf.pdf 